\title{
Internal Displaced Persons (IDPs): A Case Study of Western Nepal
}

Sabin Bahadur Zoowa, Student

Kathmandu Shiksha Campus

\begin{abstract}
In Nepal, the number of IDPs appeared to have increased mainly due to the decade long CPN (Maoist) insurgency that hit the country since 2052 BS (1995 AD). Apparently, the IDPs are compelled or forced to undergo the critical circumstances due to the very condition of their displacement. Likewise, mostly, the incidents of excesses such as murder, torture, rape, sexual assault, kidnapping, forceful recruitment in the army are perpetrated against the IDPs. So, different causes make the people to be displaced. Towards this, natural disaster, human-made circumstances and disasters, armed conflict and situation of violence and fears having created there from, persons and families are forcefully displaced from their homes or places of their habitual residence. Hence, the fact is that internally displaced persons are compelled to spend traumatic lives because of internal displacement and at the same time various new problems are, owing to pressure of displaced persons, arising even in the places where they are spending displaced lives. Therefore, the state is required to play a lead role to prevent internal displacement, provide security to displaced persons, protect human rights, make provisions for immediate relief and necessary humanitarian support and service as well as facility and also make appropriate provisions for their return to their place of habitual residence or settling them voluntarily in other places in the country.
\end{abstract}

Keywords: Insurgency, displacement, vulnerabilities, conflict, human rights etc.

\section{Introduction}

Internally displaced persons are "persons or groups of persons who have been forced or obliged to flee or to leave their homes or places of habitual residence, in particular as a result of or in order to avoid the effects of armed conflict, situations of generalized violence, violations of human rights or natural or human-made disasters, and who have not crossed an internationally recognized State border." (Guiding Principles on Internal Displacement, Introduction, Para. 2)

National Policies on Internally Displaced Persons, 2007 defines, "Internally Displaced Person means a person who is living somewhere else in the country after having forced to flee or leave one's home or place of habitual residence due to armed conflict of situation of violence or gross violation of human rights or natural disaster or human made disaster and situation or with an intention of avoiding the effects of such situation." 


\section{Causes of internal displacement}

Initially, internal displacement was caused due to the numerous developmental activities and the unprecedented natural disasters though the number of IDPs has increased alarmingly due to the effect of armed conflict that hit the country since 2052 BS (1995 AD). As of today, the estimated figure of the IDPs is 200 to 250 thousands in accordance with the report produced by various organizations and agencies. Following are the major causes of the Internal Displacement

- Armed conflict started in 2052 BS (1995 AD) and the fear of cross fire, terror, intimidation by the parties involved in the conflict, murder and torture.

- The emancipation of the bonded laborers (Mukta Kamaiya) on 2nd Shrawan 2057 BS (17th July, 2000 AD) that has led them to be displaced following the lack of proper arrangement of food, shelter and clothing for them.

- The land acquirement for the purpose of hydro project, road construction, irrigation, airport construction, establishment of the national parks, watershed management etc.

- The establishment of the barracks for the security forces in the villages

- The loss of the places of habitual residence, land properties due to the natural disaster such as flood, landslide, earthquake and wildfire that occur from time to time leaving the local inhabitants high and dry

\section{Internal displaced persons as a vulnerable}

Although all persons affected by conflict and/or human rights violations suffer, displacement from one's place of residence may make the internally displaced particularly vulnerable. Internally displaced persons may be in transit from one place to another, may be in hiding, may be forced toward unhealthy or inhospitable environments, or face other circumstances that make them especially vulnerable. Especially groups like children, the elderly or pregnant women, may experience profound psychosocial distress related to displacement. Internally displaced persons may lack identity documents essential to receiving benefits or legal recognition that may face language barriers during displacement and schooling for children and adolescents may be disrupted.

\section{Methodology of the study}

A statistical sampling method for the selection of the research sites and respondents is not possible for a study of this nature since there is no systematic and reliable data source. The purpose of this study is, therefore, to visit and conduct the study in 
an area where they are most prevalent. Three districts Banke, Bardiya and Surkhet were selected for the study and visited there. The purpose of this study is to generate basic information about internally displaced persons (IDPs). Thus, checklists were developed to conduct the interview. The interviews were also tape-recorded which were transcribed later in Kathmandu. The interviews were held in a very congenial atmosphere that was non-threatening and acceptable to the respondents.

Different groups of displaced people such as squatter in Banke district, Kamaiya in Bardiya district and conflict induced displaced people in Surkhet were interviewed. These interviews were successfully conducted in their camps with the help of community based organizations (CBOs), NGOs, INGOs and local government offices. SPOSH Nepal, Freed Kamaiya Society and CIS Nepal have supported respectively in Banke, Bardiya and Surkhet districts. In this study, both primary and secondary data were used. Primary data were collected from interview schedule whereas the secondary data were collected from different stakeholders. Few meetings and focus group discussion (FGD) were also organized with conflict induced displaced persons who were from Kalikot, Humla, Jumla, Salyan and Dailekh districts and living in Birendranagar, Surkhet district.

The main objectives of the research are to know the general situation of internally displaced persons, to depict their cause, present situation and major facing problems and to advocate and draw the attention of state for their welfare and rehabilitation.

\section{Result and discussion}

The following groups of people who were force to leave their place and living in the camps and forest land with very minimum basic facilities were known to be internally displaced people in this research. The major findings with relation to their situation and the state role are as follows:

\section{Kamaiya}

Kamaiya system was a complex farm wage labor system prevalent in eight districts of west, mid-west and far western Terai districts of Nepal. The people involved in Kamaiya system are mainly from Tharu ethnic group who are simple, native and innocent by nature. The Government of Nepal in 17 July 2000 abolished the practice rendering the system illegal and annulled all hitherto incurred debts incurred by the Kamaiyas. After the declaration, the freed Kamaiyas were forced to leave from their landlord's house and were moving from camp to camp seeking for food, land and shelter. Though the government does not have any concrete plan, the Kamaiyas have force to live in the open forestland. They don't have any commodities brought with them in the time of liberation. So they have displaced and living in anywhere where accessible by them. 


\section{Squatter}

The government definition for genuine squatter - that is those who not only are living on land without permission, but have no land holdings elsewhere, and financially cannot afford to find housing elsewhere. Following the definition under government, even those who have a house elsewhere may not be able to move into that house for lack of space, or afford to rent space. The tendency of increasing squatter is in a great deal. Continued in-migration of low-income people from peripheral and rural areas in urban cities or nearby highway in search of jobs, reduction of cheaper rental accommodations within the reach of their job stations, increasing land values and costs of building materials, lack of effective land use plan and regulation have given ways to illegal encroachment of public unattended land and buildings to develop into unplanned squatter settlements. The main cause of being squatter or the relation to be displacement becoming squatter are presence of caste discrimination in the society, present political conflict, employment opportunity, education, flood and landslide, earthquake, internal conflict within the family, emerging nuclear family and fire caught etc. Even if the displaced squatters are ignored, they will not disappear; they will find someplace else to squat.

\section{Conflict induced displacement}

Conflict induced displacement in Nepal started with the beginning of the Maoists' 'People's War'. With the deterioration of the security situation in 2001, in many mid and far western districts the Maoists expanded their intimidation and violence practices targeting landowners, members of the ruling party, VDC chairmen and wealthy people. As a result, most of them decided to migrate to the district headquarters in search of safety. Likewise, some government officials and teachers under threat from the Maoists have been forced to migrate from their villages. The declaration by the Maoists of the "district people's government" strategy in August 2001 and the beginning of forced recruitment from every family of one young man or woman, prompted the increased exodus of young people to India. In addition, the military pressure from the security forces since the imposition of the state of emergency in November 2001 has further increased the migration of especially males aged 13-28. Registration for IDPs in district administration office is open but the IDPs forced to leave due the security forces are not encouraged to register there. They are rather arrested and kept in custody or are disappeared by the state. Those IDPs who have been displaced due to the rebels and their place of destination are the district headquarters can only register for them but others living other than district headquarters remains unregistered. They have to rather hide either in relatives' house or cross the border to India pretending to search for job. 


\section{Conclusion}

IDPs are often a neglected group, and their needs should be assessed on a regular basis, at all phases of displacement (emergency, post-emergency, return or resettlement). However, the IDP definition should not be used as a means to define target groups for assistance or protection programmes, as IDPs are not a homogenous group. Based on assessments, it is recommended to target those IDPs who have a special vulnerability, because of their ethnic origin, their access to assistance and services, their socialeconomic status, etc. Also, the needs of host populations in areas of displacement, return or resettlement should be given attention, as the resources of these communities are often shared with IDPs, or can also be affected by the conflict or the disaster.

\section{References}

Action by Churches Together (2000, September 11). Emergency relief for freed bonded laborers - ASNP01. Norwegian Refugee Council, Geneva, Switzerland.

Caritas Nepal (2005). Caravan of conflict: A Study of the dynamics of conflict-induced displacement in Nepal. Kathmandu. Caritas Nepal.

Community Study and Welfare Centre (2004, February 1). Plight of internally displaced persons (IDPS) in Nepal: A call for an urgent intervention by the HMG/Nepal, United Nations, and international community. Kathmandu: Author.

Ghimire. A (2007). Enfranchising IDPs in Nepal. Kathmandu: Author.

GTZ, INF, SNV, UNDP/RUPP, NHRC \& the Global IDP Project (2003). Nepal internal displaced people research initiative findings. Kathmandu: Author.

Human Rights without Frontiers International (2005). Internally displaced persons in Nepal: forgotten victims of the conflict. Brussels. Belgium.

Informal Sector Service Center (2004). Armed conflict and internal displacement in Nepal: human rights yearbook. Kathmandu: Author.

International Nepal Fellowship (2004). Research report on internally displaced people of western region, Nepal. Kathmandu: Author.

Lutheran World Federation (2003). The kamaiyas - former bonded laborers of Nepal. Kathmandu: Author.

National Legislative Bodies/National Authorities (2007 January 1). National Policies on Internally Displaced Persons. Kathmandu: Author.

Tulsi Panthee (2007). The socio-economic impact of internal displacement due to armed conflict: A study of western Nepal. Social Inclusion Research Fund Secretariat (SIRF), Lalitpur.

United Nations (1998). Guiding Principles on Internal Displacement. New York. 